\title{
PEMBERDAYAAN PEREMPUAN DALAM PEMERATAANNYA DI LINGKUNGAN
}

\author{
M. Shalahuddin Hijratullah \\ Email: 2010128210021@mhs.ulm.ac.id \\ Program Studi Pendidikan IPS Fakultas Keguruan dan Ilmu Pendidikan \\ Universitas Lambung Mangkurat \\ Banjarmasin
}

\begin{abstract}
Abstrak
Pada umum nya pemberdayaan merupakan proses peningkatan kesadaran dan pembangunan kapasitas, dengan tujuan partisipasi yang lebih besar, kekuasaan dan pengawasan yang lebih besar terhadap pengambilan keputusan, dan tindakan transformatif untuk mencapai kesetaraan yang lebih besar antara laki-laki dan perempuan. Dalam artikel ini disajikan apa saja tingkatan pemberdayaan perempuan dan juga prinsip pada pemberdayaan perempuan.
\end{abstract}

\section{PENDAHULUAN}

Pemberdayaan dapat diartikan sebagai proses memperoleh kekuasaan, kekuatan, dan kemampuan, atau proses pemberian kekuasaan, kekuatan, dan kemampuan kepada pihak-pihak yang memiliki kekuasaan yang semakin sedikit. Otorisasi mengacu pada pemberdayaan individu atau kelompok yang telah diberi kewenangan kepada individu atau masyarakat, sehingga memiliki kemampuan yang diotorisasi.

Menurut undang-undang Nomor 20 Tahun 2008 tentang asas dan tujuan pemberdayaan, pemberdayaan bertujuan untuk meningkatkan perekonomian masyarakat, meningkatkan pendapatan dan kesejahteraan masyarakat, serta memperluas lapangan kerja bagi masyarakat untuk mengatasi kemiskinan.

Pemberdayaan perempuan dipandang sebagai proses peningkatan kesadaran dan pembangunan kapasitas, dengan tujuan partisipasi yang lebih besar, kekuasaan yang lebih besar dan pengawasan pengambilan keputusan, dan tindakan transformasional untuk 
mencapai kesetaraan yang lebih besar antara laki-laki dan perempuan. Upaya pemberdayaan perempuan dapat dilakukan dengan cara menyadarkan dan membantu mengembangkan potensi yang ada sehingga perempuan menjadi manusia yang mandiri. Perempuan dapat memainkan peran penting dalam meningkatkan sosial ekonomi masyarakat. Perempuan dapat memainkan peran penting di sektor ekonomi formal dan informal melalui kreativitas dan inovasinya, sehingga menjadi motor penggerak pembangunan. Dalam artikel ini disajikan bagaimana

\section{TINGKAT PEMBERDAYAAN PEREMPUAN}

Dalam pemberdayaan perempuan terdapat lima tingkatan pemerataan. Yang pertama adalah pemerataan manfaat. Jika pada awalnya kelompok ini berharap untuk diberi wewenang, tetapi tidak memiliki aset ekonomi, tidak memiliki kesempatan untuk meningkatkan kemampuan ekonominya, dan tidak sejahtera, maka tentu kita tidak dapat membebaskan mereka dari penderitaan. Kedua, akses kesempatan yang adil adalah meningkatkan kemampuannya masuk jurusan untuk memperoleh informasi, memperoleh kesempatan kerja, dan memperoleh kesempatan pendidikan yang baik setara dengan lakilaki. Setelah akses diberikan, langkah selanjutnya adalah bagaimana meningkatkan visibilitas. Ketiga, pemerataan kesadaran. Jika kesadaran seperti ini muncul, maka mereka harus bisa memperbaiki diri, dan dapat menyadari apa kebutuhannya. Setelah penyadaran, selanjutnya adalah peningkatan atau pemerataan partisipasi aktif. Keempat, partisipasi yang setara. Perempuan tidak lagi dianggap sebagai tujuan atau sasaran pembangunan, tetapi berpartisipasi dalam perencanaan, pelaksanaan dan evaluasi program yang mereka laksanakan. Kelima, kekuasaan didistribusikan secara merata. Pada tingkat pengambilan keputusan ini, partisipasi perempuan pasti akan berdampak pada pemberdayaan. Jika jenis partisipasi ini digunakan, akses perempuan ke sumber daya ekonomi akan memburuk dan memastikan distribusi sumber daya dan pembagian keuntungan yang adil.

\section{PRINSIP PEMBERDAYAAN PEREMPUAN}

Kesetaraan, inilah prinsip utama dari proses pemberdayaan. Kesetaraan di sini mengacu pada kesetaraan status antara masyarakat dengan lembaga yang melaksanakan 
rencana pemberdayaan masyarakat dan antara laki-laki dan perempuan. Dengan membangun mekanisme saling berbagi pengetahuan, pengalaman dan keahlian, maka terjalinnya hubungan yang setara merupakan motivasi timbal balik yang masing-masing mekanisme mengenali kekuatan dan kelemahannya masing-masing, sehingga terwujud suatu proses pembelajaran bersama.

Kemudian yang kedua adalah partisipasi, dalam rencana pemberdayaan yang dapat mendorong kemandirian masyarakat adalah rencana yang melibatkan partisipasi masyarakat, perencanaan, pelaksanaan, pengawasan dan evaluasi. Berikutnya adalah kemandirian. Prinsip kemandirian adalah menghargai dan mengedepankan kemampuan masyarakat, bukan bantuan pihak lain. Konsepnya bukanlah memperlakukan orang miskin sebagai objek ketidakberdayaan, tetapi memperlakukan mereka sebagai objek dengan kemampuan kecil. Mereka memiliki kemampuan untuk menabung, memiliki pemahaman yang mendalam tentang batasan bisnis, mengetahui kondisi lingkungan mereka, memiliki tenaga dan kemauan, serta memiliki norma sosial yang terhormat. Semua ini harus dieksplorasi dan digunakan sebagai dasar untuk proses otorisasi.

Yang terakhir adalah keberlanjutan, meskipun peran pendamping lebih penting daripada masyarakat itu sendiri pada awalnya, rencana otorisasi juga harus dirancang agar berkelanjutan. Namun seiring berjalannya waktu, peran pendamping pasti akan semakin berkurang.

\section{KESIMPULAN}

Pemberdayaan merupakan proses peningkatan kesadaran dan pembangunan kapasitas, dengan tujuan partisipasi yang lebih besar, kekuasaan dan pengawasan yang lebih besar terhadap pengambilan keputusan, dan tindakan transformatif untuk mencapai kesetaraan yang lebih besar antara laki-laki dan perempuan. Dalam pemberdayaan perempuan terdapat 5 tingkat yaitu: pemerataan manfaat, akses kesempatan yang adil, pemerataan kesadaran, partisipasi yang setara, kekuasaan didistribusikan secara merata. Dalam prinsipnya yaitu : kesetaraan, partisipasi, kemandirian, dan keberlanjutan. Dan itu semua harus diperhatikan dalam pemberdayaan perempuan. 


\section{REFERENSI}

Arisanty, D., Normelani, E., Putro, H. P. N., \& Anis, M. Z. A. (2017). The role of women in Lok Baintan Floating Market, South Kalimantan: implication for tourism development. Journal of Indonesian Tourism and Development Studies, 5(3), 169174.

Mualifah, N., \& Roekminiati, S. (2018). Pemberdayaan Masyarakat Kampung Inggris Sebagai Destinasi Wisata Edukasi di Kecamatan Pare Kabupaten Kediri. Jurnal Ilmiah Manajemen Publik dan Kebijakan Sosial, 2(1), 168-182.

PEREMPUAN, P. OLEH LAJNAH WANITA DAN PUTRI AL-IRSYAD SURABAYA.

Saptandari, P. (1999). Lima Tingkat Pemberdayaan Perempuan. Masyarakat Kebudayaan dan Politik, Th XII, (2).

Wibowo, E. P. (2019). PEMBERDAYAAN PEREMPUAN MELALUI KELOMPOK BUDIDAYA IKAN "MINA LESTARI" DALAM MENINGKATKAN KESEJAHTERAAN KELUARGA DESA BENDILJATI WETAN KECAMATAN SUMBERGEMPOL KABUPATEN TULUNGAGUNG (PERSPEKTIF EKONOMI ISLAM). 